\title{
ФАКТОРЫ, ВЛИЯЮЩИЕ НА ФОРМИРОВАНИЕ РЕКРЕАЦИОННО-ОЗДОРОВИТЕЛЬНЫХ КОМПЛЕКСОВ В УКРАИНЕ
}

Скороходова А. В., Харьковский национальный университет строительства и архитектуры; дочент; кандидат архитектурыл; Украина

Родик Я. С., Харьковский нацииональный университет строительства и архитектуры; доцент; кандидат архитектуры; Украина

Даниленко Е. Л., Харьковский национальный университет строительства и архитектуры; дочент; кандидат архитектурыл; Украина

DOI: https://doi.org/10.31435/rsglobal_ws/31032020/6967

\section{ARTICLE INFO}

Received: 15 January 2020

Accepted: 12 March 2020

Published: 31 March 2020

\section{KEYWORDS}

recreational and health complexes, architectural environment, rehabilitation, architectural and planning design solutions.

\begin{abstract}
The main factors affecting the formation of recreational and health complexes in Ukraine are identified in the article. Importance of unique recreational potential of Ukraine and establishment of recreational and health rehabilitation facilities is proved. The research indicates that modern recreational and health complex is a synergy of natural potential, the latest rehabilitation and medical technologies, professionalism of employees and uniqueness of architectural solutions. The significance of architectural solutions goes beyond aesthetic perception and comfort. Architecture of these objects significantly affects the person's physical health due to elaborate location of the building, its area-based planning and design of facades and interiors. Proposals for optimal placement of recreational and health complexes and their volume-spatial and functional planning solutions can be developed only as a result of analysis of economic, social, climatic and urban factors.
\end{abstract}

Citation: Скороходова А. В., Родик Я. С., Даниленко Е. Л. (2020) Factors Influencing the Formation of Recreational and Health Complexes in Ukraine. World Science. 3(55), Vol.1. doi: 10.31435/rsglobal_ws/31032020/6967

Copyright: ( 2020 Скороходова А. В., Родик Я. С., Даниленко Е. Л. This is an open-access article distributed under the terms of the Creative Commons Attribution License (CC BY). The use, distribution or reproduction in other forums is permitted, provided the original author(s) or licensor are credited and that the original publication in this journal is cited, in accordance with accepted academic practice. No use, distribution or reproduction is permitted which does not comply with these terms.

Введение. Положительные изменения социально-экономической обстановке в Украине, постепенное улучшение социального уровня населения усиливают потребность общества в отдыхе, оздоровлении и заботе о своем здоровье. Назрела необходимость в оптимизации деятельности рекреационных и здравоохранительных объектов в стране с целью повышения качества услуг оздоровления, реабилитации и восстановительного лечения для населения.

Правительство Украины наметило масштабные планы по улучшению фонда объектов здравоохранения и строительству новых медицинских, реабилитационных и рекреационнооздоровительных объектов в стране. Сегодня новыми приоритетными направлениями государственной социальной политики Украины стала профилактическая медицина, нацеленная на укрепление здоровья граждан, повышение доступности и качества медицинской помощи, развитие первичной медицинской помощи, возрождение профилактического направления в здравоохранении и обеспечение населения высокотехнологичной оздоровительной помощью. [1]

Законодательная база в сфере здравоохранения обновляется, ведь сегодня современное общество предъявляет высокие требования к медицинским и оздоровительным объектам. Однако сами здания учреждений здравоохранения и курортно-санаторного лечения остались прежними и в большинстве случаев не соответствуют современным требованиям. В то же время в международной практике именно восстановительная медицина признана одним из приоритетных направлений развития здравоохранения. [2] Особое место в этой системе занимает рекреационно- 
оздоровительная помощь, спецификой которой является оказание услуг по восстановлению здоровья на основе преимущественного применения природных лечебных факторов. В современном понимании рекреационно-оздоровительное учреждение предназначено для расширенного воспроизводства физических, интеллектуальных и эмоциональных сил человека.

Результаты исследования. Под рекреацией (лат. recreatio - восстановление) понимается комплекс оздоровительных мероприятий, осуществляемых с целью восстановления нормального самочувствия и работоспособности здорового, но утомлённого человека. Как элемент социальной сферы, рекреация способствует не только сохранению здоровья и рабочей способности, но отдыху и удовлетворению культурно-просветительных потребностей человека.[3] Это многосложный процесс, который осуществляется, в самом общем виде, в следующих формах: оздоровительного отдыха, туризма, курортно-санаторного лечения. Одним из путей удовлетворения потребностей населения в оздоровлении и отдыхе является формирование рекреационных-оздоровительных комплексов.

В зависимости от функционального назначения, уровня специализации и преимущественного развития того или иного рекреационного потенциала, выделяют различные типы рекреационно-оздоровительных объектов:

- санаторно-курортный (по функциональным особенностям предназначается для санаторно-курортного лечения и включает в себя специализированные санаторно-лечебные однопрофильные и многопрофильные учреждения);

- реабилитационный (по функциональным особенностям предназначается для медицинской и социальной реабилитации людей с инвалидностью, восстановления после медицинского вмешательства и травм, включает в себя специализированные многофункциональные объекты);

- туристско-оздоровительный (предназначается для различных видов туризма и отдыха, основными предприятиями этого комплекса являются дома отдыха, туристские гостиницы, базы, лагеря);

- оздоровительный - охотничье-рыболовный (по функциональному назначению служит для организации спортивной охоты и рыбной ловли, его основные учреждения);

- комплексный (включает в себя все или несколько видов рекреационной и оздоровительной деятельности и соответствующих ей учреждений обслуживания). [4]

Теория и практика планирования и реализации рекреационно-оздоровительных объектов охватывает широкий комплекс социальных, функциональных, санитарно-гигиенических, техникоэкономических и архитектурно-композиционных задач, которые взаимосвязаны со строительством новых и реконструкцией существующих объектов здравоохранения. [5]

Один из важнейших факторов, влияющих на строительство и архитектуру рекреационно-оздоровительных учреждений, - политическое и экономическое состояние страны. Реальное улучшение экономической ситуации и сферы здравоохранения в Украине за последние годы способствует развитию рекреационно-оздоровительных комплексов, реанимации существующей материально-технической базы объектов здравоохранения и разработки актуальных природоохранных мероприятий.

Немало важным является то, что рекреационно-туристическая индустрия является привлекательным инструментом для экономического развития многих стран. На сегодняшний день рекреационно-оздоровительный бизнес может стать для Украины важной сферой развития внутренней экономики, способной приносить доход, определять занятость населения и активно пополнять бюджет.

Существенным фактором, непосредственно, влияющим на формирование рекреационнооздоровительных объектов, является демографическая ситуация в стране. К ней относятся ретроспективные показатели численности населения всей страны, семейный состав, характеристика населения по состоянию здоровья и способности к самообслуживанию, динамика рождаемости, заболеваемости и смертности. [6] При всей важности экономических и социальных факторов, для формирования и развития рекреационно-оздоровительных комплексов, главное место занимают благоприятные природно-климатические условия. Именно они являются одной из основных материальных предпосылок рекреации и оздоровления.

Украина имеет большой рекреационный потенциал. По совокупности природноклиматических составляющих самыми благоприятными территориями Украины являются Крым и регионы Карпатских гор, так же интересными с точки зрения рекреационно- 
туристических возможностей представляются районы берегов Азовского моря, Закарпатья, Волыни и Полтавщины. [7] Украина обладает всеми необходимыми условиями для развития рекреационно-оздоровительного бизнеса: уникальными природно-ландшафтными и историкокультурными объектами.

Размещение рекреационно-оздоровительных комплексов зависит от местных природных ресурсов и ландшафта территории. Природно-климатические особенности места строительства оказывают существенное влияние на архитектуру. К природным воздействиям в первую очередь относятся: температурный, влажностный и ветровой режимы и т.д. Для обеспечения благоприятных экологических условий при строительстве необходимо учитывать ландшафт, инсоляционный режим, температурные показатели, господствующее направление ветров, что позволит оптимально располагать оздоровительные объекты, вспомогательные и жилые здания. Эти условия должны учитываться уже на уровне разработки генерального плана рекреационно-оздоровительных объектов.

Вовлечение в рекреационное использование ранее не тронутых благоприятных сочетаний природных ресурсов может стать не только исходной базой экономического развития новых территорий, но и существенно повлиять на специализацию давно сложившихся территорий. Наряду со своеобразной, неповторимой природой большой интерес для рекреации представляют памятники истории, культуры и архитектуры. В качестве рекреационных ресурсов целесообразно рассматривать и этнографические особенности населения Украины, обладающего самобытной духовной культурой.

Важно понимать, что даже при высокой привлекательности природных ресурсов без наличия коммуникаций, средств связи, коммунальной и транспортной инфраструктуры, памятников культуры и искусства развитие рекреации и туризма невозможно. Здесь важным является связь рекреационно-оздоровительных объектов с существующей инфраструктурой и размещением в сложившейся урбанизированной среде.

К градостроительным факторам проектирования рекреационно-оздоровительных комплексов относятся: место нахождения, пропорции и величина участка строительства, архитектура окружающей застройки, градостроительные ориентиры, функциональная насыщенность, специфика природного ландшафта. [8] Основным планировочным мероприятием по охране природы является функциональное зонирование территории, при котором ее отдельные участки нужно отводить под различные виды использования в соответствии с их природными особенностями (плодородные земли, ценные ландшафты, земли удобные под строительство, и т.д.).

Только в результате анализа экономических, социальных, природно-климатических и градостроительных факторов могут быть разработаны предложения по оптимальному размещению рекреационно-оздоровительных комплексов и их объемно-пространственные и функционально-планировочные решения.

Украина может развить свою экономику и туризм, улучшить сферу здравоохранения путем разработки и строительства уникальных архитектурно-планировочных проектов многофункциональных рекреационно-оздоровительных комплексов, обладающих всеми современными требованиями по комфорту и удобствам.

Выводы. Три важнейших социальных фактора - труд, здоровье и отдых населения. Они определяют круг конкретных задач: строительство учреждений, обеспечивающих отдых, лечение и оздоровление населения. На сегодняшний день Украина нуждается в новых современных объектах здравоохранения и раскрытии своего уникального рекреационного потенциала. Рекреационный потенциал Украины - это единая система природно-климатических, лечебно-оздоровительных и социально-культурных подсистем, характеризующихся функциональной взаимосвязанностью и территориальной целостностью, которая будет развиваться, и совершенствоваться благодаря созданию рекреационно-оздоровительных объектов.

Современный рекреационно-оздоровительный комплекс - это синергия природного потенциала, новейших реабилитационных и медицинских технологий, профессионализма сотрудников и неповторимости архитектурных решений. Значимость последних выходит за рамки эстетического восприятия и комфорта. Благодаря продуманному месту расположения здания, его объемно-планировочному решению, дизайну фасадов и интерьеров архитектура этих объектов существенно влияет на физическое состояние и здоровье человека. 
При проектировании рекреационно-медицинских объектов необходимо использовать принципы эколого-средового подхода, учитывать региональные особенности демографии и природно-климатических условий, градостроительные и архитектурные особенности, экономическое и санитарно-техническое состояния региона строительства.

\section{ЛИТЕРАТУРА}

1. МО3 України: Що було, є і буде. - 62 c. https://moz.gov.ua/moz-ukrainy-scho-bylo-e-i-bude.

2. Klein. R. Why Britain is reorganizing its national health service - yet again. - 1998. - Health Affairs (Millwood), 17(4): 111-25.

3. Рекреационный комплекс // Энциклопедия Экономиста [сайт]. URL: http://www.grandars.ru/shkola/geografiya/rekreacionnye-resursy.html

4. Альмухамедова О.А., Чубко Ю.В. Рекреационный комплекс: типы, задачи и условия формирования // Современные наукоемкие технологии. - 2014. - № 7-2. - С. 150-152; URL: http://www.toptechnologies.ru/ru/article/view?id=34459

5. Marmor. T.R. Hope and hyperbole: the rhetoric and reality of managerial reform in health care. - 1998. Journal of Health Services Research and Policy, 3(1).

6. Чисельність населення // Державна служба статистика України. Статистична інформація. Демографічна та соціальна статистика. Населення та міграція. http://www.ukrstat.gov.ua.

7. Вековая циклическая изменчивость основных природных экологических факторов на юго-востоке Украины / И. Д.Соколов, Е. Д. Долгих, Е. И. Соколова, О. А. Мостовой // Экологическая безопасность: проблемы и пути решения : Материалы IV Международной научно-практической конференции. - Харьков, УкрНИИЭП, 2008. - С. 98 - 102.

8. Rood. A.B. The impact of organizational and managerial factors on the quality of care in health care organizations. - 1994. - Medical Care Research and Review. 